\title{
Застосування LCP-б.локованих пластин у лікуванні діафізарних переломів ключиці
}

\author{
YU. O. HRUBAR, S. V. HARIYAN, I. V. BURBELA, M. YU. HRUBAR
}

SHEI "Ternopil State Medical University by I. Ya. Horbachevsky"

ME of TRC "Ternopil University Hospital"

\section{THE USE OF LCP PLATES IN THE TREATMENT OF FRACTURES OF THE CLAVICULAR SHAFT}

\begin{abstract}
Авторами проведено аналіз результатів застосування LСР-блокованих пластин при остеосинтезі переломів діафізарної частини ключиці. У проміжку часу понад один рік було виявлено результати лікування $40(78,43 \%)$ пацієнтів, і в 92,5 \% випадків досягнуто консолідації перелому при функціональних результатах плечового суглоба з боку перелому в межах 85-100 балів. Використання клінічно адаптованої класифікації переломів ключиці Robinson значно полегшує вибір методики остеосинтезу та тип фіксації кісткових уламків при переломах діафізарної частини ключиці. Одним із чинників, що викликали розлади репаративної регенерації при переломах ключиці, за результатами дослідження, слід
\end{abstract} вважати величину зміщення уламків та число кісткових фрагментів.

The authors made an analysis of the results of using the LCP-plates in osteosynthesis of fractures of the clavicular shaft. The results of treatment were studied in $40(78.43 \%)$ patients in terms of more than 1 year, in $92.5 \%$ of cases the fracture consolidation was achieved with the 85-100 functional points of shoulder joint on the side of the fracture. Using clinically adapted Robinson classification of fractures of the clavicle facilitates the selection of methods and type of fixation of bone fragments in fractures of the clavicular shaft. Based on the results of the study one of the factors that caused the bone consolidation disorder in fractures of the clavicle should be considered the range of debris dislocations and the number of bone fragments.

Постановка проблеми і аналіз останніх досліджень та публікацій. Переломи ключиці - доволі часте ушкодження опорно-рухового апарата, і вони виникають як у дорослих, так і дітей. Їх частота становить 12,5-26,1 \% від усіх переломів у пацієнтів, які перебувають на амбулаторному лікуванні, та 44 \% від переломів кісток плечового пояса $[1,13]$.

Найчастіше переломи ключиці виникають у діафізарній частині $-75 \%$, а причиною їх виникнення $€$ непряма травма, яка у 84,9 \% випадків є наслідком падінь у побуті [3]. Переломи зі значним зміщенням кісткових уламків діагностуються в 86,9 \% пацієнтів, а в 18,7-25,2\% випадків вони не піддаються репозиції [2]. Крім того, зростає кількість випадків переломів зі складною формою руйнування кісткової тканини після високоенергетичної травми [17].

Незважаючи на значну кількість випадків переломів ключиці, до сьогодні відсутня єдина тактика у виборі методів лікування. Переломи, що виникали в діафізарній частині ключиці, класично розглядали як показання до консервативної тактики лікування. Величина та кількість кісткових фрагментів, зміщення на 2 см і більше були оцінені як ризики до заздалегідь прогнозованих незадовільних результатів консервативного лікування, які можуть сягати 31 \% [12, 16, 15].
Майже неможливо використовувати зовнішню іммобілізацію при множинних переломах ребер, тяжких забоях органів грудної клітки, “флотуючих” переломах плеча [6, 14].

S-подібна форма ключиці перешкоджає стабільній фіксації кісткових уламків фіксаторами при їі інтрамедулярному остеосинтезі та не забезпечує ротаційної стабільності фрагментів, тому в більшості випадків це змушує додатково застосовувати зовнішню іммобілізацію [7, 9, 20].

Апарати позавогнищевої фіксації (АПФ) при переломах діафізарної частини ключиці слід вважати оптимальним засобом фіксації кісткових уламків з точки зору забезпечення їх стабільності порівняно 3 інтрамедулярним остеосинтезом [8]. Однак їх застосування при переломах вказаної локалізації викликало збільшення кількості випадків ускладнень запального характеру довкола фіксуючих елементів (до 19 \%). До того ж ускладнюються конструкції апаратів, а їх монтаж можуть забезпечити лише травматологи високої кваліфікації в операційних, обладнаних спеціальною апаратурою $[4,5]$.

Застосування накісткових пластин при діафізарних переломах ключиці в 16,8 \% викликало стандартні ускладнення: сповільнену консолідацію перелому, 
нестабільність виконаного остеосинтезу, формування несправжніх суглобів [19].

В останні роки поліпшення результатів лікування переломів кісток пов'язують з розробкою та впровадженням у практику остеосинтезу блокованих компресуючих пластин (LCP). Зокрема, фіксація блокованою компресуючою пластиною (LCP), яка може бути вигнутою до S-подібної кривизни ключиці та забезпечити стабільну анатомічну фіксацію уламків, $\epsilon$ найпріоритетнішою [10].

Мета роботи: визначити показання та ефективність застосування блокованих компресуючих пластин (LCP) у лікуванні діафізарних переломів ключиці при підходах використання клінічно адаптованої класифікації переломів.

Матеріали і методи. В основу роботи покладено аналіз результатів лікування 51 хворого з переломами діафізарної частини ключиці, в яких остеосинтез був проведений з використанням блокованих (LCP) пластин. У групі, де проводили дослідження, чоловіків було 40 (78,43 \%), жінок - 11 (21,57 \%). Середній вік чоловіків становив $(26 \pm 7,60)$ року, жінок - $(24 \pm$ $7,25)$ року. 3 переломами правої ключиці перебували на лікуванні 32 пацієнти, лівої - 19. Вивчаючи анамнез травми, встановлено, що при переломах ключиці як у чоловіків, так і в жінок домінував непрямий механізм травми - всього 49 пацієнтів (96,07 \%), лише у 2 (3,93 \%) травмованих достовірною причиною травми був прямий механізм ушкодження. При непрямому механізмі травми домінували падіння на витягнуту руку чи ділянку плеча з боку ушкодження або тулуб - 24 (48,98 \%) випадки. Під час дорожньотранспортних пригод травмувалося 10 (20,41 \%) пацієнтів. У 7 пацієнтів причиною переломів ключиці були падіння з велосипеда, скутера, мотоцикла. Падіння з висоти (будівельні конструкції, дерева, дахи) стало причиною переломів у 5 (10,21 \%) потерпілих. Спортивна травма стала причиною переломів ключиці в 3 (6,12 \%) пацієнтів. Дорожньотранспортні пригоди, падіння з висоти, спортивна травма були головною причиною переломів ключиці у чоловіків (55 \%), натомість у жінок причиною більшості переломів було падіння на ділянку плеча 3 боку перелому (67,6 \%).

Супутні пошкодження були виявлені у 19 (37,25 \%) пацієнтів. Закрита черепно-мозкова травма (струс головного мозку) була найпоширенішим супутнім пошкодженням та виявлена в 11 (57,89 \%) хворих. Переломи ребер діагностовано у 5 (26,33 \%) травмованих. У 3 з них переломи ребер ускладнилися пневмотораксом, у 2 - гемотораксом, що вимагало дренування грудної порожнини. Із “флотуючим” переломом плеча лікувалося 3 (15,78 \%) пацієнти.
При госпіталізації в стаціонар пацієнти підлягали стандартній процедурі обстеження. В більшості випадків діагноз перелому ключиці встановлювали на етапі опитування та огляду пацієнта, і він не викликав будь-яких труднощів. Клінічний діагноз усім пацієнтам був встановлений протягом перших 24 год з моменту отримання травми.

Рентгенографію ділянки перелому виконували в стандартній передньо-задній та аксилярній проекціях (кут нахилу рентгенівської трубки 45) для підтвердження та оцінки типу перелому. Переломи ключиці були класифіковані згідно із системою Robinson [18]. Відповідно до вказаної класифікації до переломів типу $R 2 A 2$ віднесено 3 (5,88 \%) пацієнтів 3 переломом ключиці. 31 перелом ключиці класифіковано як тип R2B1, з них: 18 (35,29 \%)- прості переломи ключиці з косою або гвинтоподібною лінією перелому (R2B1a) та 13 (25,49 \%) переломів ключиці з наявністю проміжного уламка трикутної форми (R2B1b). До переломів типу $R 2 B 2$ віднесено 17 переломів ключиці. 3 них 12 (23,53 \%) багатоосколкові переломи (R2B2b) та 5 (9,81 \%) пацієнтів із сегментарними переломами діафізарної частини ключиці (R2B2a).

Результати досліджень та їх обговорення. Після клінічного обстеження та передопераційної підготовки пацієнти були прооперовані під загальним знеболюванням у положенні на спині з валиком у міжлопатковій ділянці. Розріз шкіри та розміри операційної рани визначали за поширеністю ушкодження кістки та розташуванням кісткових уламків. Значну увагу приділяли репозиції кісткових уламків, що давало можливість відновити анатомічну довжину оперованої ключиці. Особливу увагу при репозиції приділяли задній та нижній стінкам ключиці з метою профілактики формування гіперпластичної мозолі, яка при обертанні ключиці, коли рука піднімається вище рівня плеча, могла тиснути на судинно-нервове сплетення підключичної ділянки, викликаючи нейронно-судинні розлади.

Довжину пластини, кількістьгвинтів таї̈функцію визначали за лінією перелому, розмірами кісткових уламків та ступенем руйнування кісткової тканини.

Виконуючи остеосинтез переломів типу R2A2, застосовували LCP-блоковані пластини, які забезпечували абсолютну стабільність кісткових уламків, створюючи при цьому компресію кісткових уламків на етапі остеосинтезу (рис. 1).

При переломах типу R2B1a проводили відкриту репозицію кісткових уламків. Створювали міжфрагментарну компресію шурупом, а пластина відігравала роль нейтралізуючої конструкції для усунення ротаційних та осьових зусиль, що діяли на кісткові уламки по лінії перелому (рис. 2 а-2 г). 


\section{З ДОСВІДУ РОБОТИ}

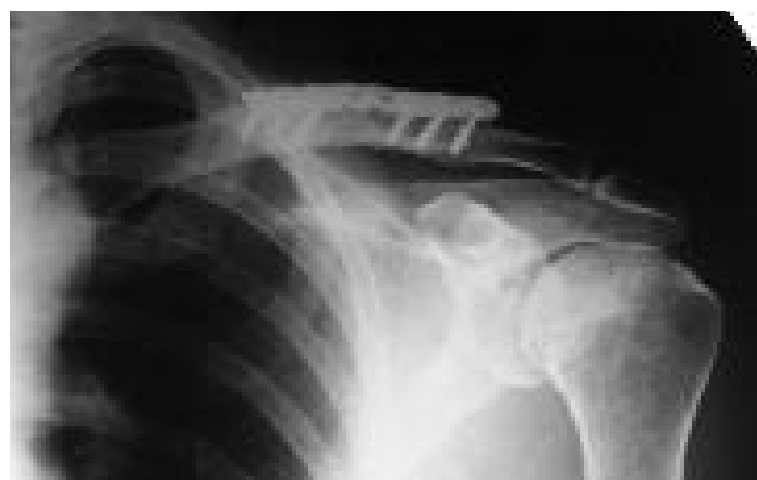

Рис. 1. Рентгенограма консолідованого поперечного перелому лівої ключиці (класифікація Robinson R2A2). Остеосинтез виконанно LCP-блокованою пластиною та гвинтами.

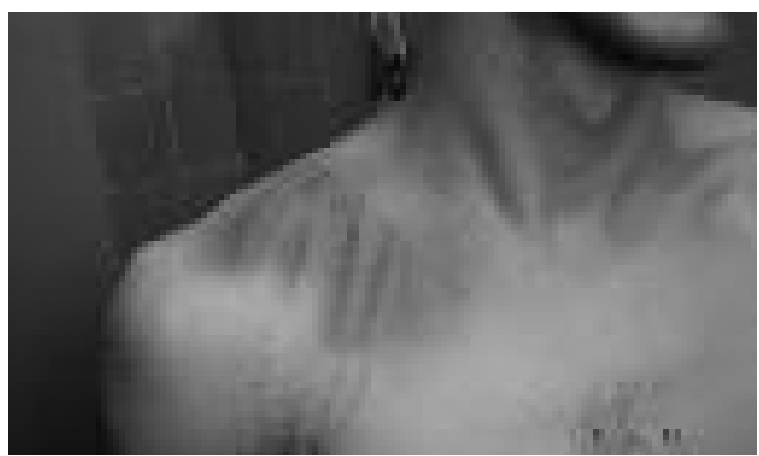

Рис. 2 а. Пацієнт М., 26 років. Вигляд ділянки перелому правої ключиці через 24 год з моменту отримання травми.

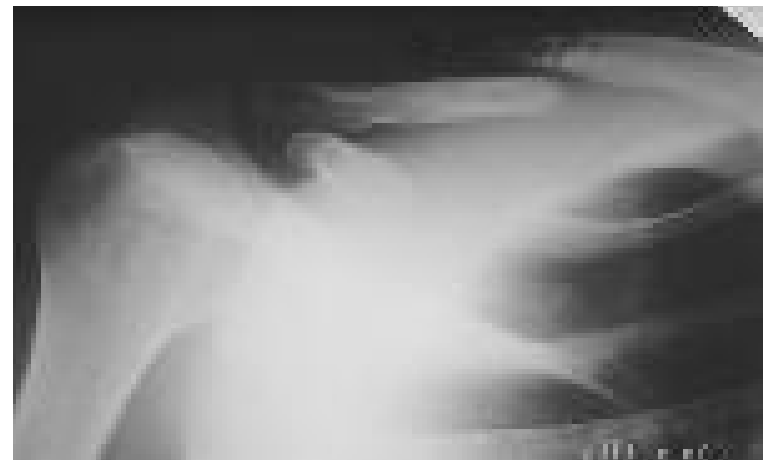

Рис. 2 б. Пацієнт М., 26 років. Пряма рентгенограма правої ключиці (класифікація Robinson, тип R2B1a).

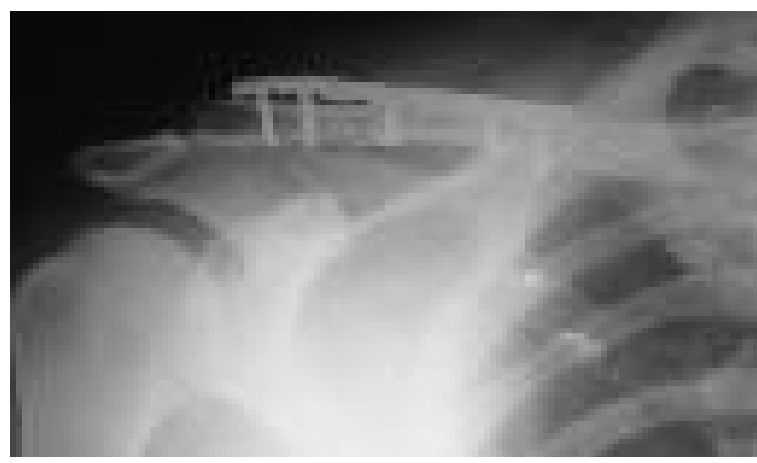

Рис. 2 в. Пацієнт М., 26 років. Пряма рентгенограма правої ключиці (класифікація Robinson, тип R2B1a). Передньо-задня контрольна рентгенограма правої ключиці через 18 місяців після втручання.

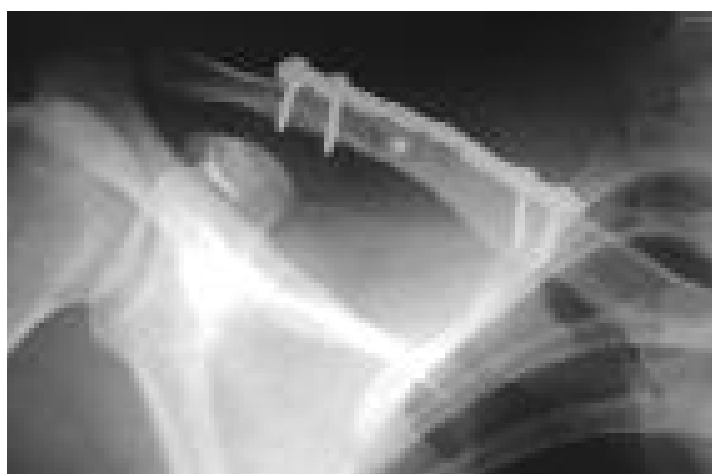

Рис. 2 г. Пацієнт М., 26 років. Пряма рентгенограма правої ключиці (класифікація Robinson, тип R2B1a). Аксилярна контрольна рентгенограма правої ключиці через 18 місяців після втручання.

При переломах типу R2B1b проводили репозицію уламків. Коли розміри уламка дозволяли провести через нього компресуючий шуруп, тоді створювали міжфрагментарну компресію, а пластина відігравала роль нейтралізуючої. Якщо неможливо було провести шуруп через уламок, - виконували репозицію уламків. Пластину моделювали по ключиці та виконували остеосинтез, що забезпечувало відносну стабільність кісткових уламків при мостоподібному типі фіксації (рис. 3 а-3 в).

При переломах типу R2B2 LCP-блоковані пластини забезпечували принцип відносної стабільності кісткових уламків при остеосинтезі та мостоподібний тип фіксації (рис. 4 а-4 г).

В усіх випадках додаткової зовнішньої іммобілізації не застосовували. 3 метою зниження больо-

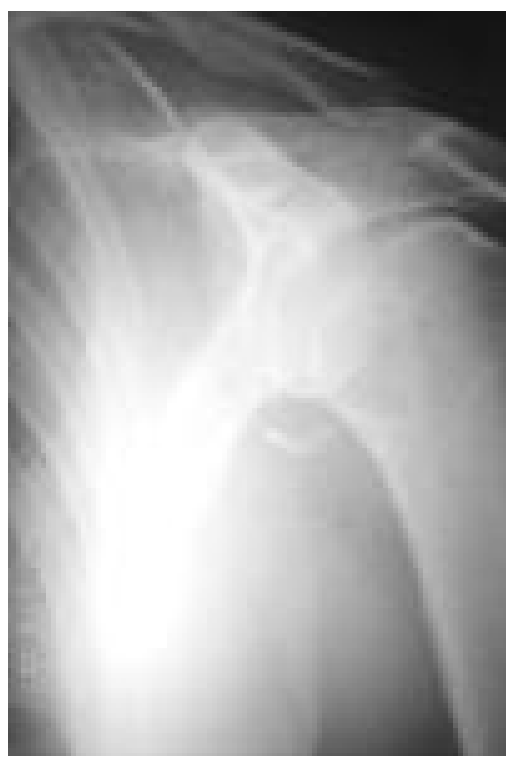

Рис. 3 а. Пацієнт С., 48 р. Передньо-задня рентгенограма лівої ключиці та плечового суглоба. Діагностовано осколковий перелом лівої ключиці зі зміщенням уламків (класифікація Robinson, тип R2B1b) та перелом шийки лівої лопатки зі зміщенням уламків (“флотуючий” перелом плеча). 


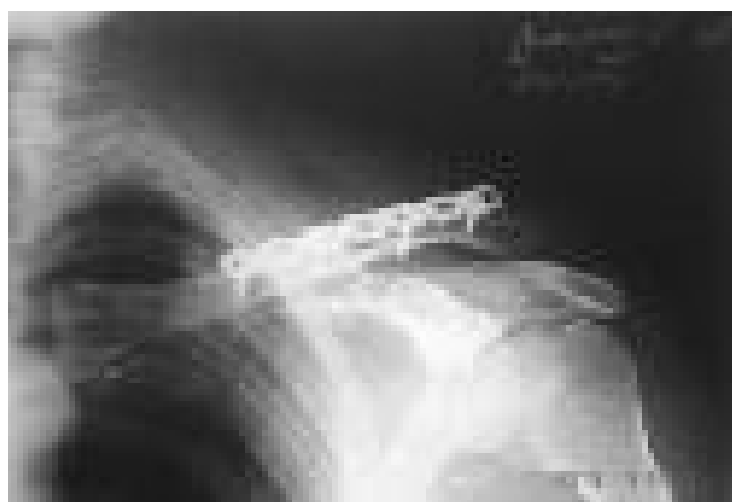

Рис. 3 б. Пацієнт С., 48 р. Контрольна передньо-задня рентгенограма лівої ключиці та плечового суглоба виконана на 3-тю добу з моменту втручання (класифікація Robinson, тип R2B1b). Металоостеосинтез лівої ключиці LCP-блокованою пластиною. Закрита репозиція перелому шийки лівої лопатки.

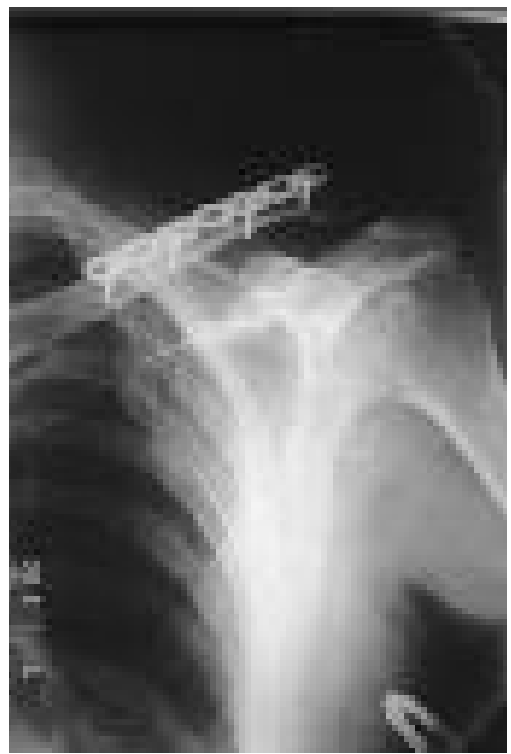

Рис. 3 в. Пацієнт С., 48 р. Контрольна передньо-задня рентгенограма лівої ключиці та плечового суглоба виконана через 13 місяців з моменту втручання.

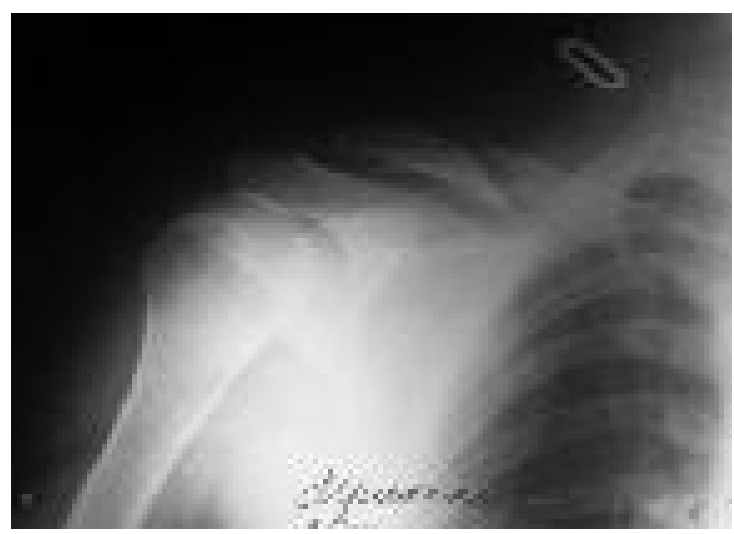

Рис. 4 а. Пацієнт М., 31 рік. Передньо-задня рентгенограма перелому правої ключиці (класифікація Robinson, тип R2B2b) у день госпіталізації.

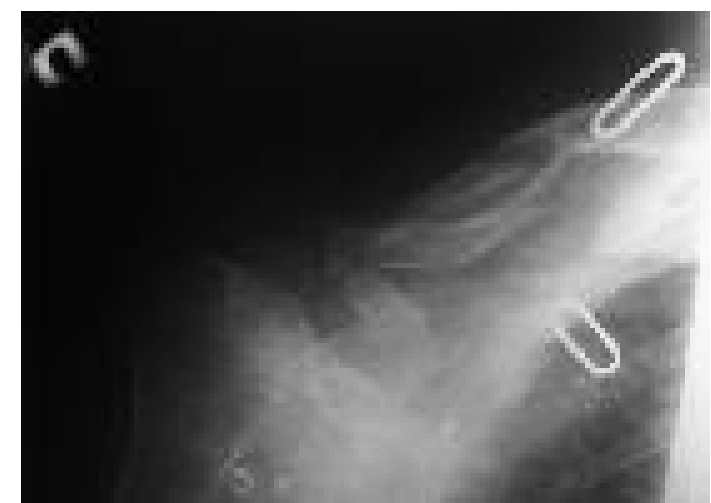

Рис. 4 б. Пацієнт М., 31 рік. Аксилярна рентгенограма перелому правої ключиці (класифікація Robinson, тип R2B2b) у день госпіталізації.

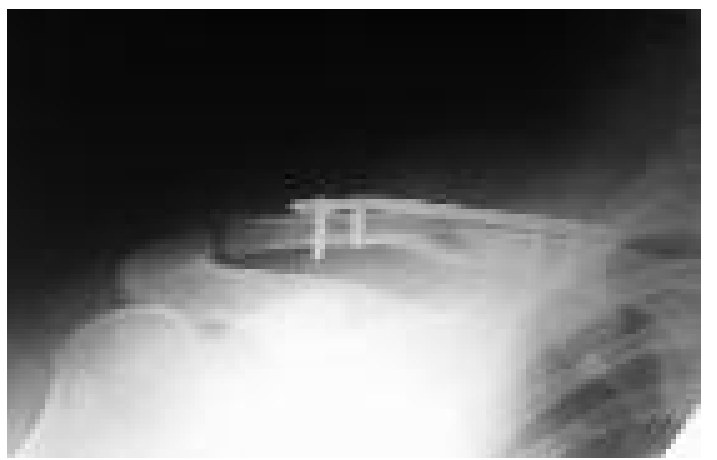

Рис. 4 в. Пацієнт М., 31 рік. Післяопераційна передньо-задня рентгенограма перелому правої ключиці (класифікація Robinson, тип R2B2b). Металоостеосинтез LCPблокованою пластиною.

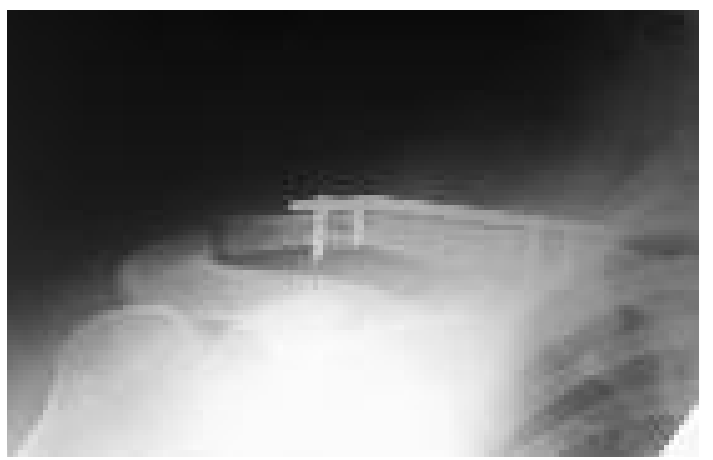

Рис. 4 г. Пацієнт М., 31 рік. Конрольна передньо-задня рентгенограма перелому правої ключиці через 6 місяців після втручання (класифікація Robinson, тип R2B2b). Металоостеосинтез LCР-блокованою пластиною.

вого синдрому пацієнтам було рекомендовано носити руку на косиночній пов'язці до 7-10 днів. ЛФК розпочинали на другу добу з моменту оперативного втручання. При виписуванні пацієнти були інструктовані про необхідність уникнення повторних навантажень на плечовий пояс упродовж наступних 3 місяців.

Ефективність застосування LCР-блокованих пластин при переломах ключиці оцінювали за якістю консолідації перелому та функції плечового суглоба 
відповідно до рекомендацій Constant C. R., Murley А. Н. (1987), адаптованих Європейською асоціацією хірургів плеча та ліктьового суглоба [11].

Контрольні рентгенограми в усіх пацієнтів виконували на 2-3-тю добу після втручання, 1,5-2 місяці та 1-1,5року після остеосинтезу, що дозволяло в динаміці спостерігати за процесом консолідації перелому, паралельно проводячи оцінку функції плечового суглоба. Ця система оцінки складалася з чотирьох показників. До суб'єктивних показників відносили біль і так званий ADL-чинник (сон, робота, відпочинок, заняття спортом), які під час обстеження дають загалом 35 балів. До об'єктивних показників належали: діапазон рухів у плечовому суглобі та м'язова сила, які дають 65 балів. Праве та ліве плече оцінювали окремо.

Всього проведено вивчення результатів лікування у 40 (78,43 \%) пацієнтів терміном понад 1 рік.

У пацієнтів 3 переломами ключиці типу R2A2 досягнуто повного зрощення перелому ключиці з результатами відновлення плечового суглоба в 100 балів.

У пацієнтів з переломами ключиці в терміни 1,52 місяці від часу втручання сповільнену консолідацію перелому типу R2B1b діагностовано в 1 (7,69 \%) випадку. При переломах типу R2B2 сповільнена консолідація перелому ключиці виявлена у 5 пацієнтів, в 1 (20 \%) пацієнта - 3 переломом типу R2B2a та в 4 (33,33 \%) пацієнтів з переломами типу R2B2b. Серед ускладнень у ранньому післяопераційному періоді було виявлено: поверхневе нагноєння рани у 3 (5,88 \%) пацієнтів з переломом типу R2B2b, в 1 (1,96 \%) випадку підшкірна гематома при переломі типу R2B2a.

\section{СПИСОК ЛІТЕРАТУРИ}

1. Алкалаев С. Б. Методы лечения переломов ключицы / С. Б. Алкалаев, М. В. Фомичёв, В. А. Копысова // Вестник Новосибирского государственного университета. - Новосибирск, 2008. - Т. 6. - Вып. 2. - Ч. 1. - С. 127-137. - (Серия “Биология, клиническая медицина").

2. Остеосинтез ключицы фиксаторами с термомеханической памятью : метод. пособие / [В. А. Копысова, В. А. Каплун, О. В. Непомнящих и др.]. - Новокузнецк : ВНПЦ ИПФ, 2002. $-14 \mathrm{c}$.

3. Мацакян А. М. Лечение переломов ключицы и их последствий на основе биомеханической концепции фиксации отломков : автореф. дисс. на соискание учёной степени канд. мед. наук. - М., 2009. - 17 с.

4. Применение аппарата внешней фиксации в лечении оскольчатого перелома ключицы при сочетанной травме / Э. В. Пешехонов, В. И. Галин, Ю. В. Задулин [и др.] // Военно-мед. журн. - 2005. - Т. 326, № 3. - С. 49-50.

5. Слободской А. Б. Оптимизация лечения пострадавших с переломами и вывихами ключицы методом чрескостного остеосинтеза / А. Б. Слободской // Настоящее и будущее технологичной медицины : тез докл. Всероссийской науч.-практ. конф. - Ленинск-Кузнецкий, 2002. - С. 43.

6. Сысенко Ю. М. К вопросу о лечении переломов ключицы / Ю. М. Сысенко, С. И. Новичков // Гений ортопедии, 2000. № 2. - C. 86-89.
У терміни 1-1,5 року після втручання несправжній суглоб діагностовано в 3 пацієнтів (7,5 \%) із досліджуваної групи: в одного пацієнта 3 переломом типу R2B2a та в двох хворих із переломом типу R2B2b. Консолідацію перелому ключиці діагностовано в 37 (92,5 \%) пацієнтів у групі, що досліджувалася. Функціональні результати плечового суглоба з боку перелому коливалися в межах 85-100 балів.

Висновки. 1. Вибір методу лікування переломів ключиці залишається до кінця не вирішеною проблемою. При переломах ключиці відзначається пошук більш ефективних методів накісткового остеосинтезу, зокрема LCP-пластин.

2. У групі, де проводили дослідження, остеосинтез LCР-блокованими пластинами переломів ключиці показав свою ефективність - зрощення перелому досягнуто в 92,5 \% пацієнтів. Особливість конструкції пластин дозволяє при використанні одного типу фіксатора застосовувати його в різних варіантах остеосинтезу кісткових уламків при переломах діафізарної частини ключиці.

3. Використання клінічно адаптованої класифікації переломів Robinson значно полегшує вибір методики остеосинтезу та тип фіксації кісткових уламків при переломах діафіза ключиці.

4. Одним із чинників, що викликали розлади репаративної регенерації при переломах ключиці, за результатами дослідження, слід вважати величину зміщення та кількість кісткових уламків.

7. Тонких С. А. Причины неудовлетворительных исходов при внутреннем остеосинтезе переломов ключицы / С. А. Тонких, В. Э. Янковский, А. А. Коломиец // Гений ортопедии, - 2004. - № 1. - С. 114-117.

8. Експериментальне дослідження механічної міцності остеосинтезу перелому ключиці в середній третині різними фіксаторами / О. А. Тяжелов, М. М. Шпаченко, В. Ю. Чернецький [та ін.] // Науковий вісник Ужгородського університету. 2007. - Вип. 32. - С. 193-199. - (Серія “Медицина”).

9. Closed reduction and internal fixation for acute midshaft clavicular fractures using cannulated screws / T. Y. Chuang, W. P. Ho, P. H. Hsieh [et al.] // J. Trauma. - 2006. - Vol. 60. - P. 1315-1320.

10. Operative treatment of clavicle midshaft fractures: comparison between reconstruction plate and locking compression plate / C. H. Chul, K. S. Song, B. W. Min [et al.] // Clin. Orthop. Surg. - 2010. - Vol. 2. - P. 154-159.

11. Constant C. R. A clinical method of functional assessment of the shoulder / C. R. Constant, A. H. Murley // Clinical Orthopaedics and Related Research. - 1987. - Vol. 214. - P. 160-164. 12. Hill J. M. Closed treatment of displaced middle-third fractures of the clavicle gives poor results / J. M. Hill, M. H. McGuire, L. A. Crosby // J. Bone Joint. Surg. Br. - 1997. - Vol. 79. - P. 537-539.

13. Fractures of the clavicle / L. A. Khan, T. J. Bradnock, C. Scott 
[et al.] // J. Bone Joint Surg. Am. - 2009. - Vol. 91. - P. 447460.

14. Kljnz A. Clavicular fractures Unfallchimrg / A. Kljnz, T. Hokkertz, H. Reilmann // J. Trauma. - 2001. - Vol. 104, № 1. - P. 7081.

15. Deficits following nonoperative treatment of displaced midshaft clavicular fractures / M. D. McKee, E. M. Pedersen, C. Jones [et al.] // J. Bone Joint Surg. Am. - 2006. - Vol. 88. - P. 35-40.

16. Nowak J. Sequelae from clavicular fractures are common / J. Nowak, M. Holgersson, S. Larsson // Acta Orthop. - 2005. Vol. 76. - P. 496-502.

17. Epidemiology of clavicle fractures / F. Postacchini, S. Gu- mina, P. De Santis [et al.] // J. Shoulder Elbow Surg. - 2002. - Vol. 11. - P. 452-456.

18. Robinson C. M. Fractures of the clavicle in the adult. Epidemiology and classifi cation / C. M. Robinson // J. Bone Joint Surg. Br. - 1998. - Vol. 80(3). - P. 476-484.

19. Plate fixation of fresh displaced midshaft clavicle fractures / W. J. Shen, T. J. Liu, Y. S. Shen // Injury. - 1999. - Vol. 30. - P. 497-500.

20. Elastic stable intramedullary nailing versus non-operative treatment of displaced midshaft clavicular fractures-a randomized, controlled, clinical trial / V. Smekal, A. Irenberger, P. Struve [et al.] // J. Orthop. Trauma. - 2009. - Vol. 23. - P. 106-112.

Отримано 23.01.15 